\title{
Towards Mechanistic Understanding of Mercury Availability and Toxicity to Aquatic Primary Producers
}

\author{
Perrine Dranguet, Rebecca Flück, Nicole Regier, Claudia Cosio, Séverine Le Faucheur, \\ and Vera I. Slaveykova*
}

\begin{abstract}
The present article reviews current knowledge and recent progress on the bioavailability and toxicity of mercury to aquatic primary producers. Mercury is a ubiquitous toxic trace element of global concern. At the base of the food web, primary producers are central for mercury incorporation into the food web. Here, the emphasis is on key, but still poorly understood, processes governing the interactions between mercury species and phytoplankton, and macrophytes, two representatives of primary producers. Mass transfer to biota surface, adsorption to cell wall, internalization and release from cells, as well as underlying toxicity mechanisms of both inorganic mercury and methylmercury are discussed critically. In addition, the intracellular distribution and transformation processes, their importance for mercury toxicity, species-sensitivity differences and trophic transfer are presented. The mini-review is illustrated with examples of our own research.
\end{abstract}

Keywords: Bioavailability $\cdot$ Macrophytes $\cdot$ Methylmercury $\cdot$ Mercury $\cdot$ Phytoplankton $\cdot$ Speciation

\section{Introduction}

Mercury $(\mathrm{Hg})$ is a priority contaminant of global concern. ${ }^{[1]}$ In most aquatic ecosystems, the main sources of $\mathrm{Hg}$ are diffuse atmospheric deposition and point sources related to industrial activities. ${ }^{[1]}$ Inorganic mercury $\left(\mathrm{Hg}^{\mathrm{II}}\right)$ and methylmercury $\left(\mathrm{CH}_{3} \mathrm{Hg}\right)$ are toxic to aquatic organisms, but $\mathrm{CH}_{3} \mathrm{Hg}$ is strongly biomagnified in the food web (Fig. 1), thus ultimately representing the main threat for humans through fish consumption. ${ }^{[2]}$ As a trace metal, $\mathrm{Hg}$ is inherently persistent. Once entered into aquatic ecosystems, $\mathrm{Hg}$ undergoes different transformation processes encompassing photoreduction, oxidation, methylation and demethylation, complexation by dissolved ligands and adsorption to colloids and particles. ${ }^{[3-5]}$ Consequently $\mathrm{Hg}$ is distributed under a variety of chemical species (Fig. 1) with differing reactivity. In surface water, $\mathrm{Hg}$ is present under several chemical forms, with elementary $\mathrm{Hg}\left(\mathrm{Hg}^{0}\right), \mathrm{Hg}^{\mathrm{II}}$ and $\mathrm{CH}_{3} \mathrm{Hg}$ as predominant species. ${ }^{[3,6]}$ The concentrations of $\mathrm{Hg}$ species decrease in the order of $\mathrm{Hg}^{\mathrm{II}}>\mathrm{Hg}^{0} \sim \mathrm{CH}_{3} \mathrm{Hg}$. ${ }^{[7]}$ In addition, $\mathrm{Hg}^{\mathrm{II}}$ and $\mathrm{CH}_{3} \mathrm{Hg}$ are bound

${ }^{\star}$ Correspondence: Prof. V. I. Slaveykova

Environmental Biogeochemistry and Ecotoxicology Institute F.-A. Forel, Earth and Environmental Sciences

Faculty of Sciences, University of Geneva

10 route de Suisse

$\mathrm{CH}-1290$ Versoix

Tel.: +412237903 35

E-mail: vera.slaveykova@unige.ch to particulate $(>0.45 \mu \mathrm{m})$, colloidal $(0.45$ $\mu \mathrm{m}-1 \mathrm{kDa})$ and truly dissolved fractions $(<1 \mathrm{kDa})$. Among the dissolved inorganic and organic ligand complexes, hydroxo- $\left(\mathrm{Hg}(\mathrm{OH})^{+}, \mathrm{Hg}(\mathrm{OH})_{2}, \mathrm{Hg}(\mathrm{OH})_{3}{ }^{-}\right.$, $\left.\mathrm{CH}_{3} \mathrm{HgOH}\right)$ and chloro- $\left(\mathrm{HgCl}^{+}, \mathrm{HgClOH}^{3}\right.$, $\left.\mathrm{HgCl}_{2}, \mathrm{HgCl}_{3}^{-}, \mathrm{HgCl}_{4}{ }^{2-}, \mathrm{CH}_{3} \mathrm{HgCl}\right) \mathrm{com}-$ plexes are predominant, but their propor- tion changes as a function of $\mathrm{pH}$ and chloride concentration. ${ }^{6]}$ Given the very strong tendency of $\mathrm{Hg}^{\text {II }}$ to form complexes, the estimated free $\mathrm{Hg}^{2+}$ concentration is extremely low e.g. below $10^{-27} \mathrm{M}$ to $10^{-28} \mathrm{M} \cdot{ }^{[8]} \mathrm{In}$ addition, in surface waters, the chemical speciation seems to be controlled by the complexes formed with fulvic and humic-

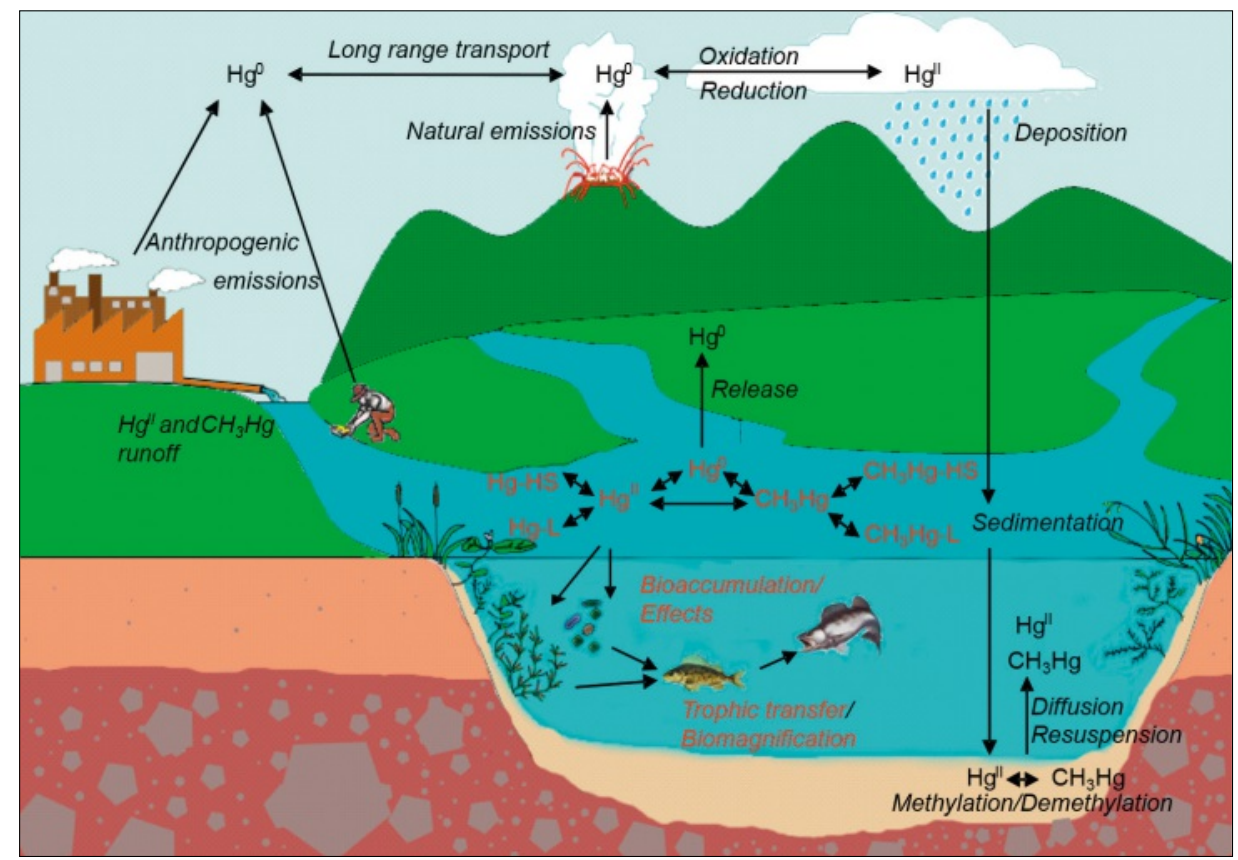

Fig. 1. Mercury biogeochemical cycle in aquatic environment. Major steps involve: (i) release of mercury $\left(\mathrm{Hg}^{0}, \mathrm{Hg}^{\prime \prime}\right)$ from natural (rock, soils, volcanoes) or anthropogenic sources (artisanal gold mining, fossil fuel combustion, chlor-alkali plants), (ii) dispersion in gaseous form $\left(\mathrm{Hg}^{\circ}\right)$ through the atmosphere, (iii) dry or wet deposition of $\mathrm{Hg}^{\prime \prime}$ on land and surface waters, (iv) sedimentation, (v) bioconversion into $\mathrm{CH}_{3} \mathrm{Hg}$, (vi) trophic transfer and bioaccumulation $\left(\mathrm{Hg}^{\prime \prime}\right.$ and $\mathrm{CH}_{3} \mathrm{Hg}$ ) and biomagnification $\left(\mathrm{CH}_{3} \mathrm{Hg}\right)$ in the food web or (vii) evasion $\left(\mathrm{Hg}^{\circ}\right)$ to the atmosphere. The processes which are the subject of the present overview, are given in red. 
like dissolved organic matter (DOM) (Fig. 2). Therefore examination of the chemical speciation, (rarely addressed) in addition to the measurement of total $\mathrm{Hg}$ concentrations, would improve the understanding of the different processes at the medium-biota interfaces.

The current activities in our laboratory focus on the study of the interactions of different $\mathrm{Hg}$ species with two major groups of primary producers: phytoplankton and macrophytes. Phytoplankton accounts for half of the primary productivity on the Earth and, as a result, sustains the largest ecosystem on our planet. ${ }^{[10]}$ Macrophytes contribute to the primary productivity in shallow waters including rivers, marshes, ponds and lakes. ${ }^{[11]}$ What is more, the primary producers are at the basis of trophic webs, providing a support to high trophic level consumers and as such represent the main pathway of $\mathrm{Hg}$ incorporation into the food webs. ${ }^{[8,12]}$ Indeed phytoplankton and macrophytes were shown to be the major entry points of $\mathrm{CH}_{3} \mathrm{Hg}$ in a fish food web in water bodies impacted by a chlor-alkali plant discharge, ${ }^{[13]}$ with a bioconcentration factor of $\mathrm{CH}_{3} \mathrm{Hg}$ reaching $10^{4}$ and greater. ${ }^{[12]}$ It is therefore of the upmost importance to understand underlying mechanisms of the interactions of $\mathrm{Hg}$ species with primary producers, its internal handling and effects, as well as its transfer from primary producers to higher trophic levels. The fate and effects of $\mathrm{Hg}$ to these two primary producers, as well as their role in its transformation processes in the environment were recently reviewed. ${ }^{[8,12,14]}$

Understanding the basic mechanisms of $\mathrm{Hg}$ bioavailability and toxicity to primary producers is part of an ongoing initiative to understand some of the key processes controlling the fate and impact of vital and toxic trace elements ${ }^{[15,16]}$ and engineered nanoparticles ${ }^{[17,18]}$ in aquatic ecosystems. This mini-review deals with the chemo- and biodynamic aspects of $\mathrm{Hg}^{\mathrm{II}}$ and $\mathrm{CH}_{3} \mathrm{Hg}$ interactions with phytoplankton and macrophytes and is illustrated with examples from our own research as well as the literature.

\section{Interactions of Mercury with Primary Producers}

Key chemo- and biodynamic processes governing the interactions of $\mathrm{Hg}^{\mathrm{II}}$ and $\mathrm{CH}_{3} \mathrm{Hg}$ with primary producers comprise: (i) transport of different forms of $\mathrm{Hg}$ from the medium to the biointerface (Fig. 3) (e.g. by diffusion); (ii) interactions with various organic and inorganic compounds forming complexes; (iii) adsorption to different sites of the biota surface (e.g. cell wall); (iv) transport across the membrane (e.g. internalization); distribution and transformation of $\mathrm{Hg}$ species inside the cell; following the interactions with intra-

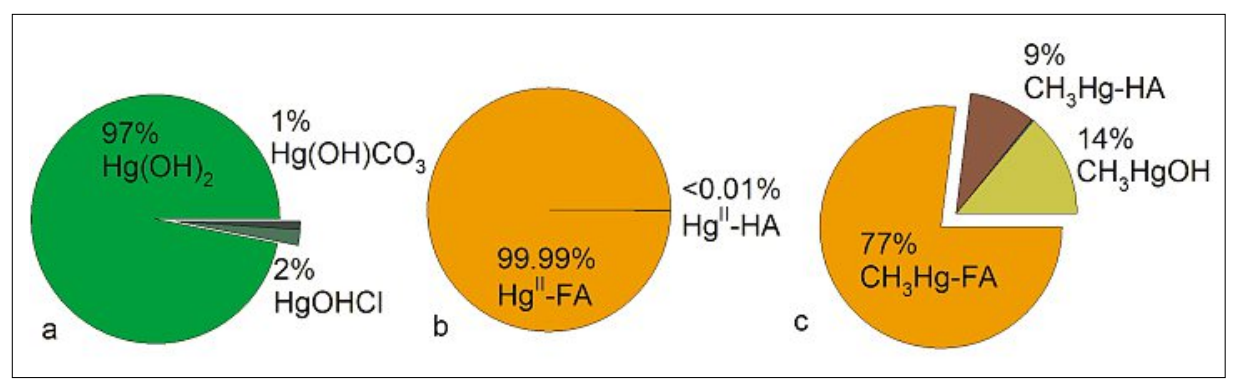

Fig. 2. Distribution of $\mathrm{Hg}$ species in a model lake water contaminated with $\mathrm{Hg}$ and containing 0.35 $\left.\mathrm{mg} / \mathrm{L}\left[\mathrm{NO}_{3}{ }^{-}\right], 9.14 \mathrm{mg} / \mathrm{L}\left[\mathrm{Cl}^{-}\right], 43.64 \mathrm{mg} / \mathrm{L}^{2} \mathrm{SO}_{4}{ }^{2-}\right], 6.2 \mathrm{mg} / \mathrm{L}\left[\mathrm{Na}^{+}\right], 1.59 \mathrm{mg} / \mathrm{L}\left[\mathrm{K}^{+}\right], 40.7 \mathrm{mg} / \mathrm{L}\left[\mathrm{Ca}^{2+}\right]$, $\left.5.9 \mathrm{mg} / \mathrm{L}^{3} \mathrm{Mg}^{2+}\right]$ at $\mathrm{pH} 8.3$ and a dissolved organic matter concentration of $0.25 \mathrm{mg} / \mathrm{L}$ humic and $2.25 \mathrm{mg} / \mathrm{L}$ fulvic acids. The water composition corresponds to that measured in $\mathrm{G} 3$ sampling point of Lake Geneva in October 2013. Speciation was computed with the WHAM/Model VII chemical equilibrium program with updated formation constants for $\mathrm{OH}^{-}, \mathrm{Cl}^{-}, \mathrm{NH}_{4}^{+}, \mathrm{PO}_{4}^{3-}$ and $\mathrm{CO}_{3}{ }^{2-} \cdot{ }^{[9]}$ (a) $3.1 \times 10^{-10} \mathrm{M}\left[\mathrm{Hg}^{\prime \prime}\right]$, only inorganic complexes are considered; (b) $3.1 \times 10^{-10} \mathrm{M}\left[\mathrm{Hg}^{\prime \prime}\right]$, DOM is taken into account; (c) $3.1 \times 10^{-12} \mathrm{M}\left[\mathrm{CH}_{3} \mathrm{Hg}\right]$, DOM is taken into account. The complexes formed with fulvic and humic acids are the prevailing forms of $\mathrm{Hg}^{\prime \prime}$ and $\mathrm{CH}_{3} \mathrm{Hg}$, as well as chloride and hydroxide complexes. Estimated free mercury concentration $\mathrm{Hg}^{2+}<10^{-30} \mathrm{M}$ and free methylmercury concentration $\mathrm{CH}_{3} \mathrm{Hg}^{2+}<10^{-15} \mathrm{M}$.

cellular components, $\mathrm{Hg}$ species can affect the cellular processes at different levels (e.g. genomic, proteomic and physiological levels); release from the cells or further translocation via intracellular (symplast) or paracellular transport (apoplast) in pluricellular organisms.

In the case of macrophytes, their exposure to $\mathrm{Hg}$ in the aquatic environment can occur either by their roots or directly by their shoots, or most frequently by both. However, submerged species usually show higher $\mathrm{Hg}$ accumulation than emerging plants found at the same sites. ${ }^{[19]}$ Accumulated $\mathrm{Hg}$ can be translocated from root to shoot or inversely. In fact, whereas $\mathrm{Hg}^{\text {II }}$ accumulated in shoots is taken up mainly directly from the water column, accumulated $\mathrm{CH}_{3} \mathrm{Hg}$ in shoots seems to originate from both the pore water of sediments and the water column. ${ }^{[20]}$

\section{Diffusion towards Biointerfaces}

To enter in contact with primary producers mercury species should first diffuse from the bulk medium to the biointerface. The diffusion flux is given by Eqn. (1):[8,21]

$$
J_{\text {diff }}=D c_{b}\left(\frac{1}{r}+\frac{1}{\delta}\right)
$$

where $r$ is the radius of the cell, $\delta$ is the thickness of the unstirred boundary layer, $D$ is the diffusion coefficient of $\mathrm{Hg}$ species, $c_{b}$ is the $\mathrm{Hg}$ concentration in the medium. Since the $\mathrm{Hg}$ concentration in surface waters is vanishingly low, very small diffusional flux could be expected. Consequently diffusion limitation of $\mathrm{Hg}$ uptake by primary producers could take place. In such a case, Hg complexes are anticipated to contribute to $\mathrm{Hg}$ fluxes towards

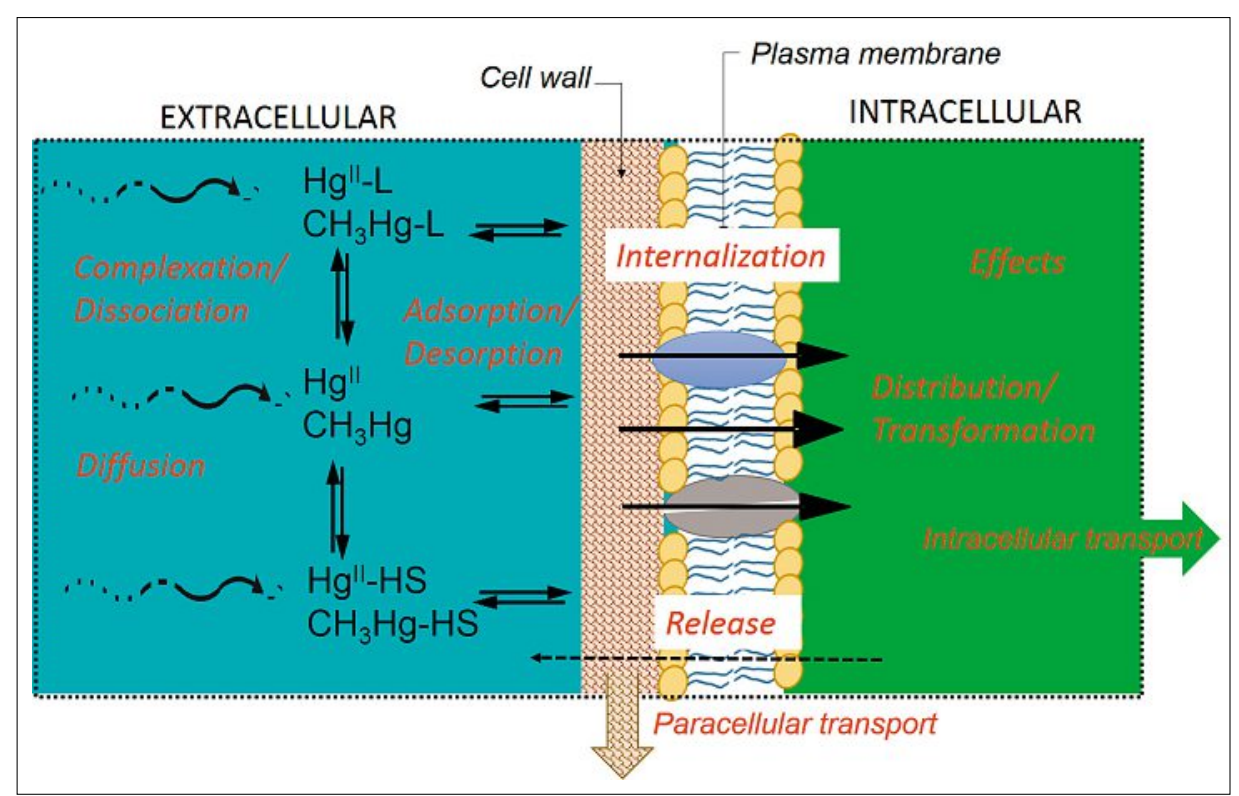

Fig. 3. Key processes determining the interactions of inorganic $\left(\mathrm{Hg}^{\prime \prime}\right)$ and methylated $\mathrm{Hg}\left(\mathrm{CH}_{3} \mathrm{Hg}\right)$ forms with primary producers. Charges are omitted for simplicity. 
cell surfaces, depending on their mobility and lability. However, there is a lack of experimental evidence supporting such chemodynamic considerations for $\mathrm{Hg}$. The experiments performed with artificial membranes demonstrated that lipophilic $\mathrm{HgCl}_{2}{ }^{0}$ uptake is controlled by the mass transport of $\mathrm{Hg}$ from the bulk medium to the membrane since the permeability coefficient in medium was about one order of magnitude lower than that through the membrane. ${ }^{[8]}$ However in most laboratory experiments, even those performed at environmentally relevant concentrations, the transport of metal across the biological membrane is estimated to be the rate-limiting step (Fig. 4), therefore the internalization flux can be directly related to the concentration of any metal species in equilibrium e.g. $\mathrm{HgCl}_{2}$ or $\mathrm{CH}_{3} \mathrm{HgCl}$.

\section{Mercury Adsorption and Internalization}

The cell wall that most of the phytoplankton species and macrophytes possess in addition to the cytoplasmic membrane represents a supplementary protective barrier. Cell wall composition can vary and may be formed of cellulose in green algae and macrophytes, peptidoglycan in cyanobacteria, and silica frustule in diatoms. Moreover cell walls contain polysaccharides and structural proteins, rich in hydroxyl-, carboxyl-, phosphate- and thiolgroups binding $\mathrm{Hg}$. Indeed, about $41 \%$ of $\mathrm{Hg}^{\mathrm{II}}$ and $27 \%$ of $\mathrm{CH}_{3} \mathrm{Hg}$ were reversibly adsorbed to Elodea nuttallii cell walls ${ }^{[25]}$ and about $88 \%$ to the cell walls of the green alga Chlamydomonas reinhardtii, ${ }^{26]} \mathrm{dem}-$ onstrating the important adsorbing role of the cell walls, in particular in $\mathrm{Hg}^{\mathrm{II}}$ binding. However the experimental distinction between $\mathrm{Hg}$ adsorbed to the cell wall and $\mathrm{Hg}$ transported inside the cells is operational and is based on the extraction by using different reagents: for example mixture of EDTA/cysteine for E. nuttallii ${ }^{[25]}$ and cysteine for $C$. reinhardtii. ${ }^{[26]}$

The precise mechanisms of $\mathrm{Hg}$ internalization by primary producers are not yet elucidated in detail, but several mechanisms were proposed: (i) simple passive diffusion of neutral lipophilic complexes, (ii) facilitated transport (e.g. via channel mediated diffusion), (iii) active transport (e.g. through the essential trace metal transporters) and (iv) indirect transport of $\mathrm{Hg}^{\mathrm{II}}$ and $\mathrm{CH}_{3} \mathrm{Hg}$ bound to amino acids or thiols. $[8,12,19,27]$

The passive diffusion of $\mathrm{HgCl}_{2}{ }^{0}$ and $\mathrm{CH}_{3} \mathrm{HgCl}^{0}$ through algal membranes was deduced to be the central mechanism of $\mathrm{Hg}$ uptake by the diatom Thalassiosira weissflogii, ${ }^{[28]}$ since $\mathrm{Hg}^{\mathrm{II}}$ and $\mathrm{CH}_{3} \mathrm{Hg}$ internalization fluxes were linearly correlated with the overall octanol-water partition coefficients, $\mathrm{K}_{\mathrm{ow}}$ of $\mathrm{Hg}$ in the exposure solutions.

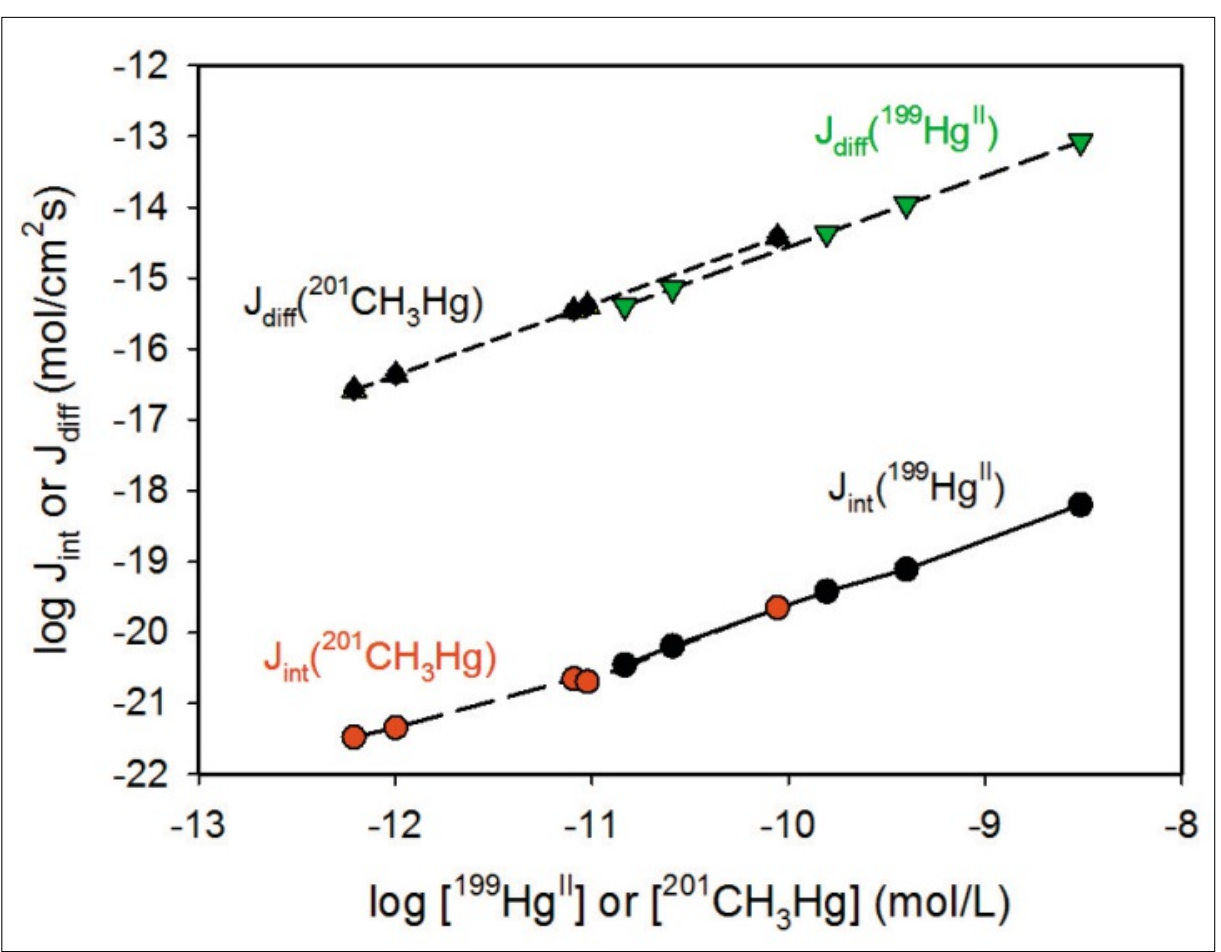

Fig. 4. Experimentally determined internalization and calculated diffusive fluxes to the green alga Chlamydomonas reinhardtii exposed to a mixture of ${ }^{199} \mathrm{Hg}^{11}$ and ${ }^{201} \mathrm{CH}_{3} \mathrm{Hg}$. The internalization fluxes were estimated from the intracellular concentrations at $48 \mathrm{~h}$ determined by double stable isotope spiking. ${ }^{[22]}$ Linear increase of the intracellular content over time was assumed. Single alga surface area is $3.2 \times 10^{-6} \mathrm{~cm}^{2}$. Diffusive flux were calculated by using Eqn. (1). Diffusion coefficients

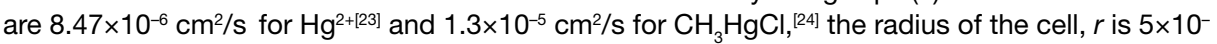
${ }^{4} \mathrm{~cm}$, the thickness of the unstirred boundary layer, $\delta$ is $8 \times 10^{-4} \mathrm{~cm} \cdot{ }^{[8]}$ Initial $\mathrm{Hg}$ concentrations at the biota surface was taken as 0 . Chemical speciation in the exposure medium taken into account is: $75.9 \% \mathrm{HgCl}_{2}, 15.7 \% \mathrm{HgClOH}_{1} 6.4 \% \mathrm{HgCl}_{3}^{-}, 89.5 \% \mathrm{CH}_{3} \mathrm{HgCl}$ and $10.5 \% \mathrm{CH}_{3} \mathrm{HgOH}$ (complex

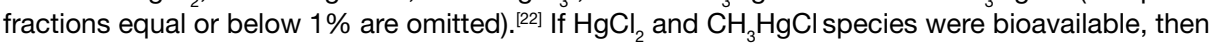
the diffusive flux would not be limiting under these conditions.

$\mathrm{Hg}^{\mathrm{II}}$ and $\mathrm{CH}_{3} \mathrm{Hg}$ form neutral lipophilic complexes: $\mathrm{HgCl}_{2}{ }^{0}$ with $\mathrm{K}_{\text {ow }}$ of 3.3 and $\mathrm{CH}_{3} \mathrm{HgCl}^{0}$ with $\mathrm{K}_{\text {ow }}^{2}$ of 1.7. ${ }^{[8,28]}$ However no uptake or toxicity was detected upon exposure to $\left(\mathrm{CH}_{3}\right)_{2} \mathrm{Hg}$ characterized with much higher $\mathrm{K}_{\mathrm{ow}}$ of 182 or $\mathrm{Hg}^{0}$ with $\mathrm{K}_{\mathrm{ow}}$ of 4.15 , demonstrating that lipophilicity of the $\mathrm{Hg}$ species is not the only factor governing $\mathrm{Hg}$ internalization.

Various evidence exists demonstrating that the $\mathrm{CH}_{3} \mathrm{Hg}$ internalization could take place by active transport. For example $\mathrm{CH}_{3} \mathrm{Hg}$ uptake rate in Selenastrum capricornutum was inhibited by chemical uncouplers such as carbonyl cyanide $m$ chlorophenylhydrazone (CCCP) or 2,4- dinitrophenol, 3-(3,4-dichlorophenyl)-1,1dimethylurea (diuron) and paraquat.[27] Metabolically dependent transport of $\mathrm{Hg}$ was further supported by the decrease of $\mathrm{CH}_{3} \mathrm{Hg}$ uptake by algae exposed to $\mathrm{CH}_{3} \mathrm{Hg}$ in the dark or exposed to $\gamma$ irradiation. ${ }^{[29]}$ Heat-killed diatoms were shown to contain less $\mathrm{CH}_{3} \mathrm{Hg}$ and $\mathrm{Hg}^{\mathrm{II}}$ in their cytoplasm compared to living cells, further suggesting a metabolically controlled uptake of both $\mathrm{Hg}$ species by the diatoms. ${ }^{[30]}$ By contrast to $\mathrm{CH}_{3} \mathrm{Hg}$, no unequivocal evidence exists for facilitated transport of inorganic $\mathrm{Hg}$ into other phytoplankton species. $\mathrm{Hg}$ uptake through essential metal transporters was demonstrated in methylating organisms, with the transport of $\mathrm{Hg}$-cysteine complexes or neutral $\mathrm{HgCl}_{2}$ being in competition with zinc for uptake. ${ }^{[31]}$ In macrophytes, unintentional transport of $\mathrm{Hg}^{\text {II }}$ by $\mathrm{Cu}$ transport system was proposed as a major route for $\mathrm{Hg}^{\mathrm{II}}$ internalization in $E$. nuttallii. ${ }^{[19]}$ The hypothesis of $\mathrm{Hg}$ uptake via high affinity $\mathrm{Cu}$ transporters was further supported by transcriptomic analysis revealing decrease of EnCOPT1 gene expression at increasing $\mathrm{Hg}^{\mathrm{II}}$ concentrations. ${ }^{[32]}$ Thus the possible involvement of $\mathrm{Hg}^{2+}$ binding to membrane transporters, is not as straightforward as for other metals. ${ }^{[15,33]}$

Similarly to other trace metals, the above-mentioned processes at the biotamedium interface can be influenced by: ${ }^{[33]}$ (i) the characteristics of the cell wall and biological membrane; (ii) the reactivity of the species towards the biological membranes; (iii) the water quality parameters, such as $\mathrm{pH}$ and water hardness; (iv) the presence and concentrations of micronutrients and toxic trace metals; (v) the presence of different ligands of natural (e.g. DOM) or anthropogenic origins affecting $\mathrm{Hg}$ speciation. However the influence of these modifying factors need still to be ex- 
plored. Below we will focus on the effect of DOM, pH, trace metals and nutrients, factors that were considered for primary producers.

There is quite inconclusive and contradictory evidence on the role of DOM on $\mathrm{Hg}$ uptake. DOM decreases $\mathrm{Hg}$ uptake in algae by strongly binding of $\mathrm{Hg}$ by reduced sulfur sites on the DOM[27,34-36] and thus reducing potentially bioavailable $\mathrm{Hg}$ fraction. In addition, the DOM concentration and quality were shown to affect the degree to which it inhibits algal $\mathrm{Hg}$ uptake. For example, $\mathrm{CH}_{3} \mathrm{Hg}$ content in the diatom Cyclotella meneghiniana decreased in the presence of DOM; however the effect was more pronounced in the presence of the highly aromatic hydrophobic fraction of DOM than in the presence of the transphilic one. ${ }^{[35]}$ By contrast, $8 \mathrm{mg} / \mathrm{L}$ DOM promoted $\mathrm{Hg}$ uptake in aquatic invertebrates $^{[37]}$ and bacteria. ${ }^{[38]}$ Low molecular weight DOM fractions enhanced $\mathrm{Hg}$ accumulation in plankton, while high molecular weight reduced it. [39]

Very few studies explored systematically the effect of different water quality parameters, including $\mathrm{pH}$ and micro- and macronutrients, on the uptake of $\mathrm{Hg}^{\text {II }}$ and $\mathrm{CH}_{3} \mathrm{Hg}$, thus their role as modifying factors is still to be elucidated. The decrease of $\mathrm{pH}$ from 6.5 to 5.5 was shown to increase the $\mathrm{HgCl}_{2}{ }^{0}$ uptake by $C$. reinhardtii by $40 \%$. [26] Little or no effect of major water quality cations was observed on the intracellular content in shoots of $E$. nuttallii exposed to $200 \mathrm{ng} / \mathrm{L}$ of $\mathrm{HgCl}_{2}$ and 2500 -fold excess of $\mathrm{Fe}^{2+}, \mathrm{Mg}^{2+}, \mathrm{Na}^{+}, \mathrm{K}^{+}$or $\mathrm{Ni}^{2+}$ (Fig. 5). However, significant inhibition of $\mathrm{Hg}^{\mathrm{II}}$ accumulation was found in the presence of $\mathrm{Cu}^{+}{ }^{+}{ }^{[19]}$ Under comparable conditions no effect of $\mathrm{Cu}$ and other tested ions on the $\mathrm{CH}_{3} \mathrm{Hg}$ uptake was observed, suggesting that both $\mathrm{Hg}$ species do not share the same transport system. High concentrations of seleno-L-methionine decreased $\mathrm{CH}_{3} \mathrm{Hg}$, but enhanced $\mathrm{Hg}^{\mathrm{II}}$ uptake in the diatom $T$. pseudonana, ${ }^{[40]}$ while no effect of selenite or selenate was detected. To explain $\mathrm{Hg}^{\mathrm{II}}$ uptake increase, the authors hypothesized that the uptake of methionine- $\mathrm{Hg}^{\mathrm{II}}$ complex is faster than that of $\mathrm{Hg}^{\mathrm{II}}$ alone. Further investigations are thus clearly needed to understand the mechanisms behind selenomethionine effects.

\section{Mercury Cellular Distribution}

Understanding intracellular distribution of $\mathrm{Hg}^{\mathrm{II}}$ and $\mathrm{CH}_{3} \mathrm{Hg}$ is pivotal for the assessment of their toxicity, species-sensitivity differences, trophic transfer and assimilation. Indeed the 'reactivity' of $\mathrm{Hg}$ distributed in various cellular fractions is different. ${ }^{[41,42]} \mathrm{Hg}$ bound to 'organelles and heat-denaturated proteins' is expected to induce stress effects in phytoplankton, whereas the fractions 'granules and heat-

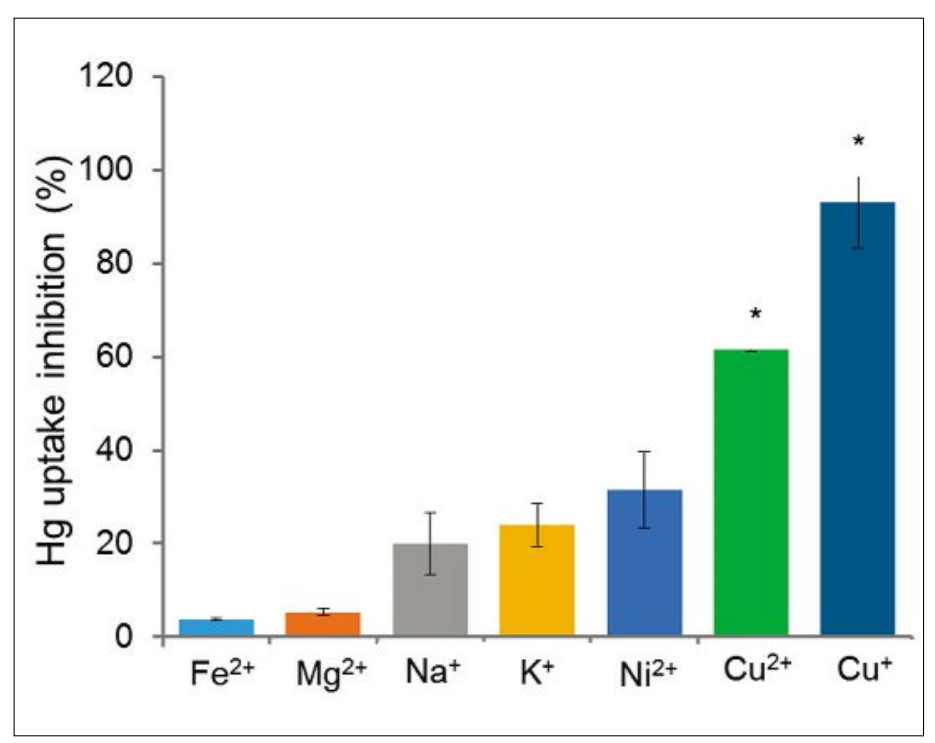

Fig. 5. Effect of different competitors on accumulation of $\mathrm{Hg}^{\prime \prime}$ in shoots of $E$. nuttallii (mean \pm s.d., $\mathrm{N}=3$ ). Macrophytes were exposed $24 \mathrm{~h}$ to $200 \mathrm{ng} / \mathrm{L}$ of $\mathrm{HgCl}_{2}$ in presence of 500 $\mu \mathrm{g} / \mathrm{L} \mathrm{Fe}^{2+}, \mathrm{Mg}^{2+}, \mathrm{Na}^{+}$, $\mathrm{K}^{+}, \mathrm{Ni}^{+}, \mathrm{Cu}^{2+}$ or $\mathrm{Cu}^{+}$. Values are expressed as percentage of inhibition of $\mathrm{Hg}$ accumulation in $E$. nuttallii exposed to $\mathrm{Hg}$ only. Asterisks indicate significant differences to $\mathrm{Hg}$ only treated plants. ${ }^{*} p<0.001$, adapted from ref. [19]

stable proteins' are expected to sequester and detoxify $\mathrm{Hg}$. The differences in species sensitivity of three phytoplankton species ${ }^{[42]}$ were shown to correlate with the proportion of $\mathrm{Hg}^{\mathrm{II}}$ in the fraction containing mitochondria and chloroplasts. By contrast intracellular $\mathrm{CH}_{3} \mathrm{Hg}$ was mainly bound to heat-stable proteins. ${ }^{[42]}$ Higher cellular $\mathrm{Hg}$ content was measured in the less sensitive organism $T$. weisflogii, while the lowest accumulation corresponded to the most sensitive species $C$. autotrophica, ${ }^{[43]}$ demonstrating that intracellular fate of $\mathrm{Hg}$ is a key factor for understanding interspecies differences. $\mathrm{Hg}$ distribution between cell wall, cell sap or membranes of the macrophyte E. nuttallii was studied in our laboratory, $-40 \%$ of the total $\mathrm{Hg}$ was bound to the cell walls, whereas $60 \%$ was in the cell sap, supposedly in the vacuole, of shoots exposed to $200 \mathrm{ng} / \mathrm{L} \mathrm{Hg}^{\text {II }}$ or $30 \mathrm{ng} / \mathrm{L} \mathrm{CH}_{3} \mathrm{Hg}^{[19]}$ Furthermore $\mathrm{CH}_{3} \mathrm{Hg}$ accumulated in the cytoplasm of diatoms was about four times more efficiently assimilated by zooplankton in comparison to $\mathrm{Hg}^{\mathrm{II}}$, which was bound to cell membranes. ${ }^{[28]}$ Similarly $\mathrm{Hg}$ accumulation and trophic transfer were comparable for four phytoplankton species with different cell walls and correlated with the cytosolic $\mathrm{CH}_{3} \mathrm{Hg}$ and $\mathrm{Hg}^{\mathrm{II}}$ fractions. ${ }^{\text {[30] }}$

\section{Mercury Intracellular Transformations}

To minimize non-specific binding of $\mathrm{Hg}^{\text {II }}$ to physiologically important biomolecules and thus prevent toxic effects, phytoplankton and macrophytes were reported to increase glutathione (GSH) cellular content, synthesize phytochelatins (PCs) and/or form metacinnabar $\beta-\mathrm{HgS}$. ${ }^{[44-46]}$ However at lower $\mathrm{Hg}$ concentrations and longer exposure time, PCs do not seem to have a noticeable role in diatoms. ${ }^{[41]}$ Therefore $\mathrm{PCs}$ role in $\mathrm{Hg}$ detoxification under environmentally relevant condi- tions remains to be confirmed. In addition, $\mathrm{CH}_{3} \mathrm{Hg}$ seems to be a poor inducer of phytochelatins. ${ }^{[47]}$ Primary producers can also sequester $\mathrm{Hg}$ as $\beta-\mathrm{HgS} .{ }^{[46,48]}$ The formation of $\beta-\mathrm{HgS}$ was found in a variety of algal species, from chlorophytes to diatoms with highest percentage formed in T. weissflogii and much lower in C. autotrophica and $I$. galbana. ${ }^{[43]}$ Reduction and demethylation of $\mathrm{Hg}$ are other intracellular transformations observed for both phytoplankton and macrophytes. Algal Hgreduction rates were shown to depend on exposure concentrations, but not on the light conditions. ${ }^{[44,45]}$ The diatom T. weissflogii exposed to $5 \mathrm{nM}$ $\mathrm{Hg}^{\mathrm{II}}$ produced comparable amount of $\mathrm{Hg}^{0}$ in the light and in the dark conditions. ${ }^{45]}$ The mechanisms by which primary producers reduce $\mathrm{Hg}$ are still to be elucidated.

Double stable isotope spiking demonstrated enrichment of intracellular ${ }^{201} \mathrm{Hg}^{\mathrm{II}}$ originating from ${ }^{201} \mathrm{CH}_{3} \mathrm{Hg}$ spike indicating the intracellular demethylation in $C$. reinhardtii when exposed to a mixture of $\mathrm{pM}$ ${ }^{199} \mathrm{Hg}^{\mathrm{II}}$ and ${ }^{201} \mathrm{CH}_{3} \mathrm{Hg} .{ }^{22]}$ The macrophyte E. nuttallii was also shown to demethylate $\mathrm{CH}_{3} \mathrm{Hg}$ in $\mathrm{Hg}^{\text {II }}$, which is further reduced to volatile $\mathrm{Hg}^{0}{ }^{.[12]}$ Methylation was also observed in the macrophyte I. aquatic after 4-day exposure to $\mathrm{HgCl}_{2}$, where $\mathrm{CH}_{3} \mathrm{Hg}$ concentration increased significantly in the shoots after additional 96-hour exposure in non-spiked medium. ${ }^{[49]}$ Phytoplankton $\mathrm{Hg}$ methylation was also investigated, but no evidence has yet been found. ${ }^{[22,46]}$

\section{Mercury Release from Cells}

Excretion of accumulated $\mathrm{Hg}$ does not seem to play significant role in the decrease of mercury accumulation in primary producers. ${ }^{[8,50]}$ Due to its strong intracellular binding, once assimilated $\mathrm{Hg}^{\mathrm{II}}$ remained within $C$. reinhardtii. ${ }^{[26]}$ To decrease cellular accumulation of $\mathrm{Hg}^{\mathrm{II}}$, some primary producers reduced intracellular $\mathrm{Hg}$ to volatile elementary $\mathrm{Hg}^{0} \cdot{ }^{[48,51,52]}$ High volatiliza- 
tion rates were measured in Euglena gracilis exposed to $5 \mu \mathrm{M} \mathrm{Hg}^{\mathrm{II}}$. ${ }^{[44]}$ Production of the gaseous $\mathrm{Hg}^{0}$ was also demonstrated to be species dependent with rates decreasing in the order C. autotrophica> I. galbana T. weissflogii. ${ }^{43]}$

\section{Mercury Toxicity towards Primary Producers}

The mode of toxic action of $\mathrm{Hg}$ involves binding to $-\mathrm{SH}$ functional groups of essential biomolecules (e.g. enzymes), displacement of essential ions from such groups, or modification of their conformation, as well as binding to active groups of ADP or ATP. ${ }^{[50]}$ At molecular level, the alteration of the electron transport activity in photosystems II, the increase of reactive oxygen species (ROS) concentrations and oxidative stress, the modification of nutrient metabolism was demonstrated in a variety of primary producers, from cyanobacteria to higher plants. ${ }^{[8,14,50]}$ Exposure to high $(\mu \mathrm{M}) \mathrm{Hg}^{\text {II }}$ concentrations reduced electron transport in photosystems II and I of cyanobacteria Nostoc muscorum, ${ }^{[53]}$ and Synechococcus, ${ }^{[54]}$ as well as decreased the quantum yield of photosynthesis and altered photosystem II photochemistry in $S$. platensis. ${ }^{[55]} \mathrm{Hg}^{\mathrm{II}}$ increased the lifetime of chlorophyll fluorescence by blocking the photosynthetic electron chain in T. weissflogii, whereas comparable concentrations of $\mathrm{CH}_{3} \mathrm{Hg}$ did not induce any effect. ${ }^{[56]}$ $\mathrm{Hg}^{\mathrm{II}}$ was also shown to substitute the $\mathrm{Mg}$ in chlorophyll molecules ${ }^{[57]}$ and to inhibit the dark reduction of plastoquinone.[58] Nanomolar concentrations of $\mathrm{Hg}^{\mathrm{II}}$ were found to affect the photosystem of six microalgal species, ${ }^{[59]}$ suggesting that alteration of photosynthesis machinery might be a plausible mechanism of $\mathrm{Hg}$ toxicity. However its significance for $\mathrm{CH}_{3} \mathrm{Hg}$ is still to be proved.

Inorganic mercury was found to affect the nutrient metabolism in primary producers. $\mathrm{Hg}^{\mathrm{II}}$ at $\mu \mathrm{M}$ concentrations reduced phosphate and nitrate uptake by Vallisneria spiralis and Azolla pinnata, ${ }^{[60]}$ probably by binging - $\mathrm{SH}$ groups of cysteine-rich nitrate reductase and inhibiting its activity. ${ }^{[61]} \mathrm{Hg}^{\mathrm{II}}$ altered the homeostasis of polyamines and the activity of ornithine decarboxylase and arginine decarboxylasein water hyacinth Eichornia crassipe. ${ }^{[62]}$ The disturbance of this homeostasis could negatively affect cell growth or even could lead to cell death. ${ }^{[63]}$ No similar studies were published for $\mathrm{CH}_{3} \mathrm{Hg}$.

Mercury was reported to increase ROS content and to induced oxidative stress in the green alga $C$. reinhardtii exposed to $\mu \mathrm{M}$ of $\mathrm{Hg}^{\mathrm{II}}{ }^{[64]}$ Both $\mathrm{Hg}^{\mathrm{II}}$ and $\mathrm{CH}_{3} \mathrm{Hg}$ induced lipid peroxidation in $C$. reinhardtii ${ }^{[65]}$ and affected membrane integrity. ${ }^{[66]}$ However, different membrane damage mechanisms were proposed for $\mathrm{Hg}^{\mathrm{II}}$ and $\mathrm{CH}_{3} \mathrm{Hg}$ : $\mathrm{Hg}^{\mathrm{II}}$ was postulated to act directly on the plasma membrane, whereas $\mathrm{CH}_{3} \mathrm{Hg}$ to disturb organelle metabolism in the cytoplasm. ${ }^{[66]}$ The generation of oxidative stress, reflected in increased lipid peroxidation in response to $\mathrm{Hg}$ exposure was also reported for several macrophyte species. ${ }^{[67-69]}$ The stress was related to the alteration of the activity of class III peroxidases, superoxide dismutase, catalase, or lipoxygenase, involved in the regulation of ROS cellular level. $[68,69]$

It is recognized that the mechanisms underlying $\mathrm{Hg}$ effects on phytoplankton and macrophytes are dependent on the $\mathrm{Hg}$ exposure concentrations. Nonetheless, almost all the reported work, described above, has been done at environmentally unrealistic concentrations $10^{3}$ to $10^{6}$ times higher than $\mathrm{Hg}$ concentrations in water, suggesting that primary producers will thus very likely not be impacted by ambient mercury concentrations at the population level in the environment. Nevertheless too few data are available for ambient water conditions to be conclusive.

Recent development of omics-approaches in our laboratory have shed new light on the $\mathrm{Hg}^{\mathrm{II}}$ effect on macrophytes. ${ }^{[32]}$ Whole transcriptome response of $E$. nuttallii exposed to increasing $\mathrm{HgCl}_{2}$ concentrations from $c a .1 \mathrm{nM}$ to $5 \mu \mathrm{M}$ revealed up-regulation of proteins (e.g. chaperones) known for their stress response function. A modification of reserve metabolism, notably sugar-catabolizing proteins, putatively caused by the inhibition of production of energy reserves by photosynthesis (Table 1). Down-regulation of metal transporters and genes related to homeostasis also appeared to most probably control and reduce accumulation of $\mathrm{Hg}^{\mathrm{II}}{ }^{[32]}$ These results support the involvement of oxidative stress and effects on protein structure as toxicity mechanism of $\mathrm{Hg}^{\mathrm{II}}$, and further highlighted that even exposure to $1 \mathrm{nM}$ resulted in significant changes in the metabolic production of energy and adaptation of the nutrition pathways as well as the induction of a protective response. On the other hand it also suggested that at environmental concentrations of $\mathrm{Hg}$ the stress level experienced by macrophytes is probably very low. These transcriptomic results are consistent with proteomic analysis demonstrating the small stress level affecting photosynthesis and therefore energy pathways as well as an adaptation of cell structure, especially through lignification in $E$. nuttallii exposed to $\mathrm{Hg}^{\text {II }}$.24] The capabilities of the next generation sequencing to determine the effects of $\mathrm{Hg}^{\mathrm{II}}$ and $\mathrm{CH}_{3} \mathrm{Hg}$ on the gene expression pattern and signature are currently explored for the green microalga $C$. reinhardtii.

\section{Conclusion and Outlook}

Important advances in the understanding of $\mathrm{Hg}^{\mathrm{II}}$ and $\mathrm{CH}_{3} \mathrm{Hg}$ bioavailability and toxicity to aquatic primary producers, such as phytoplankton and macrophytes were achieved. The interactions of $\mathrm{Hg}$ with primary producers are governed by linked chemodynamic and biodynamic processes. However the understanding of these linkages is still partial and obtained with experiments with single organism exposed to contaminant present at concentrations several orders of magnitude higher than those encountered in ambient waters. Indeed, understanding these interactions in the presence of multiple stressors and contaminant mixtures, assessment of $\mathrm{Hg}$ effects with phytoplankton communities rather than individual species represent examples of future research priorities. The development of the new stable isotopebased methods ${ }^{[22]}$ and effect-oriented tools, such as biosensors ${ }^{[70,71]}$ and -omics tools ${ }^{[32]}$ would provide further impetus of the understanding of key interactions between $\mathrm{Hg}$ and primary producers under environmental conditions.

\section{Acknowledgment}

This mini-review is reflective of a part of the work performed in the lab over the past four years. This work was supported by Swiss National Science Foundation projects IZERZ0-142228 and 205321-138254, as well as SER COST-FA0906 project C11.0117.

Received: September 2, 2014

[1] UNEP. 'Global Mercury Assessment 2013: Sources, emissions, releases, and environmental transport', 2013.

[2] C. T. Driscoll, R. P. Mason, H. M. Chan, D. J. Jacob, N. Pirrone, Environ. Sci. Technol. 2013, 47, 4967.

[3] T. A. Douglas, L. L. Loseto, R. W. Macdonald, P. Outridge, A. Dommergue, A. Poulain, M. Amyot, T. Barkay, T. Berg, J. Chetelat, P. Constant, M. Evans, C. Ferrari, N. Gantner, M. S. Johnson, J. Kirk, N. Kroer, C. Larose, D. Lean, T. G. Nielsen, L. Poissant, S. Rognerud, H. Skov, S. Sorensen, F. Wang, S. Wilson, C. M. Zdanowicz, Environ. Chem. 2012, 9, 321.

[4] C. C. Lin, N. Yee, T. Barkay, 'Environmental Chemistry and Toxicology of Mercury', Eds. G. Liu, Y. Cai, N. J. O'Driscoll, Wiley, Hoboken, New Jersey, 2012, p. 155.

[5] E. E. Vost, M. Amyot, N. J. O'Driscoll, 'Environmental Chemistry and Toxicology of Mercury', Eds. G. Liu, Y. Cai, N. J. O'Driscoll, Wiley, Hoboken, New Jersey, 2012, p. 193.

[6] K. J. Powell, P. L. Brown, R. H. Byrne, T. Gadja, G. Hefter, S. Sjöberg, H. Wanner, Pure Appl. Chem. 2005, 77, 739 .

[7] K. Leopold, M. Foulkes, P. Worsfold, Anal. Chim. Acta 2010, 663, 127

[8] S. Le Faucheur, P. G. C. Campbell, C. Fortin, V. I. Slaveykova, Environ. Toxicol. Chem. 2014, 33, 1211.

[9] E. Tipping, S. Lofts, J. E. Sonke. Environ. Chem. 2011, 8, 225.

[10] G. S. Bañuelos, H. A. Ajwa, L. Wu, S Zambrzuski, J. Soil Contamin. 1998, 7, 481 
Table 1. MIPS functional categories whose genes were significantly enriched $(p<0.05$; FDR $<0.05)$ in a dose-dependent manner (fold change $>2)$ in response of $E$. nuttallii to $\mathrm{Hg}$ treatment (adapted from ref. [32])

\section{Functional Category}

01 Metabolism

02 Energy

10 Cell cycle and DNA processing

\begin{abstract}
14 Protein fate (folding, modification, destination)
\end{abstract}

16 Protein with binding function or cofactor requirement

\section{Regulation of Metabolism and protein function}

20 Cellular transport, transport

facilities and transport routes

\section{Up-regulated}

01.02.03 sulfur metabolism

01.05.02 sugar, glucoside, polyol and carboxylate metabolism

01.05.02.07 sugar, glucoside, polyol and carboxylate catabolism

01.20 secondary metabolism

01.20.01 metabolism of primary metabolic sugar derivatives

01.20.01.07 metabolism of glycosides

02.10 tricarboxylic-acid pathway (citrate cycle Krebs cycle, TCA cycle)

10.03 cell cycle

10.03.02 meiosis

10.03.05 cell cycle dependent cytoskeleton

reorganization

10.03.05.01 spindle pole body/centrosome and microtubule cycle

10.03.05.03 cell cycle dependent actin filament reorganization

14.01 protein folding and stabilization

14.10 assembly of protein complexes

16.02 peptide binding

16.06 motor protein binding

16.17.01 calcium binding

16.21.08 Fe/S binding

18.02.01.02 enzyme inhibitor
30 Cellular communication/signal transduction mechanism

32 Cell rescue. defense and virulence

34 Interaction with the environment
30.01 cellular signalling

30.01.09 second messenger mediated signal transduction

32.01 stress response

\subsubsection{5 heat shock response}

34.03 membrane excitability 34.03.01 synaptic transmission 34.03 .03 regulation, generation and propagation of action potential

34.05.02 motor activity

34.11 cellular sensing and response to external stimulus

34.11.09 temperature perception and response

42.05 centrosome

\section{Down-regulated}

01.01.03 assimilation of ammonia, metabolism of the glutamate group 01.02 nitrogen, sulfur and selenium metabolism

01.05.05 C-1 compound metabolism

01.05.05.04 C-1 compound anabolism 01.05.05.07 C-1 compound catabolism

01.05.07 C-3 compound metabolism
20.01 transported compounds (substrates)

20.01.01 ion transport

20.01.01.01 cation transport $\left(\mathrm{H}^{+}, \mathrm{Na}^{+}\right.$,

$\mathrm{K}^{+}, \mathrm{Ca}^{2+}, \mathrm{NH}_{4}^{+}$, etc.)

20.01.01.01.01 heavy metal ion transport $\left(\mathrm{Cu}^{+}, \mathrm{Fe}^{3+}\right.$, etc. $)$

20.01.01.07 anion transport

20.01.03 C-compound and carbohydrate transport

20.01.15 electron transport

20.03 transport facilities

20.09.18.07 non-vesicular cellular import

\subsection{7 detoxification}

32.07.05 detoxification by export

34.01 homeostasis

34.01.01 homeostasis of cations

34.01.01.01 homeostasis of metal ions

$\left(\mathrm{Na}^{+}, \mathrm{K}^{+}, \mathrm{Ca}^{2+}\right.$ etc. $)$

\section{Biogenesis of cellular} components 
[11] T. Noges, H. Luup, T. Feldmann, Aq. Ecol. 2010, 44, 83.

[12] C. Cosio, R. Fluck, N. Regier, V. I. Slaveykova, Environ. Toxicol. Chem. 2014, 33, 1225.

[13] A. G. Bravo, C. Cosio, D. Amouroux, J. Zopfi, P.-A. Chevalley, J. E. Spangenberg, V. G. Ungureanu, J. Dominik, Wat. Res. 2014, 49, 391.

[14] D. S. Gregoire, A. J. Poulain, Metallomics 2014, 6, 396.

[15] V. I. Slaveykova, K. J. Wilkinson, Environ. Chem. 2005, 2, 9.

[16] I. B. Karadjova, V. I. Slaveykova, D. L. Tsalev, Aq. Toxicol. 2008, 87, 264.

[17] N. Von Moos, V. I. Slaveykova, Nanotoxicology 2014, $8,605$.

[18] N. Von Moos, P. Bowen, V. I. Slaveykova, Environ. Sci.: Nano 2014, 1, 214.

[19] N. Regier, F. Larras, A. G. Bravo, V. G. Ungereanu, C. Cosio, Chemosphere 2013, 90, 595.

[20] N. Regier, B. Frey, B. Converse, E. Roden, A. Grosse-Honebrick, A. G. Bravo, C. Cosio, PLOS One 2012, 7, e45565.

[21] V. I. Slaveykova, K. J. Wilkinson, Environ. Sci. Technol. 2002, 36, 969.

[22] A. G. Bravo, S. Le Faucheur, M. Monperrus, D. Amouroux, V. I. Slaveykova, Environ. Poll. 2014, 192, 212.

[23] R. Mills, V. Lobo, 'Self-diffusion in electrolyte solutions', Elsevier, Amsterdam, 1989.

[24] G. Gill, N. Bloom, S. Cappellino, C. Driscoll, C. Dobbs, L. McShea, R. Mason, J. Rudd, Environ. Sci. Technol. 1999, 33, 663.

[25] F. Larras, N. Regier, S. Planchon, J. Pote, J. Renaut, C. Cosio, J. Haz. Mat. 2013, 263, 575.

[26] S. Le Faucheur, C. Fortin, P. G. C. Campbell, Environ. Chem. 2011, 8, 612.

[27] H. A. Moye, C. J. Miles, E. J. Phlips, B. Sargent, K. K. Merritt, Environ. Sci. Technol. 2002, 36, 3550.

[28] R. P. Mason, J. R. Reinfelder, F. M. M. Morel, Environ. Sci. Technol. 1996, 30, 1835.

[29] A. Dhaka, V. Viswanath, A. Patapoutian, An. Rev. Neurosci. 2006, 29, 135.

[30] P. C. Pickhardt, N. S. Fisher, Environ. Sci. Technol. 2007, 41, 125.
[31] J. K. Schaefer, A. Szczuka, F. M. M. Morel, Environ. Sci. Technol. 2014, 48, 3007.

[32] N. Regier, L. Baerlocher, M. Muensterkoetter, L. Farinelli, C. Cosio, Environ. Sci. Technol. 2013, 47, 8825.

[33] M.-L. Tercier Waeber, S. Stoll, V. Slaveykova, Arch. Sci. 2012, 65, 119

[34] P. R. Gorski, D. E. Armstrong, J. P. Hurley, D. P. Krabbenhoft, Environ. Poll. 2008, 154, 116.

[35] A. C. Luengen, N. S. Fisher, B. A. Bergamaschi, Environ. Toxicol. Chem. 2012, 31, 1712.

[36] H. Zhong, W.-X. Wang, Environ. Sci. Technol. 2009, 43, 8998.

[37] T. D. French, A. J. Houben, J.-P. W. Desforges, L. E. Kimpe, S. V. Kokelj, A. J. Poulain, J. P. Smol, X. Wang, J. M. Blais, Environ. Sci. Technol. 2014, 48, 3162.

[38] S. A. Chiasson-Gould, J. M. Blais, A. J. Poulain, Environ. Sci. Technol. 2014, 48, 28.

[39] M. C. Dieguez, C. P. Queimalinos, S. R. Guevara, M. Marvin-Dipasquale, C. S. Cardenas, M. A. Arribere, J. Environ. Sci. 2013, $25,1980$.

[40] W. Wang, R. S. K. Wong, J. Wang, Y. Yen, Aq. Toxicol. 2004, 68, 39.

[41] M. Lavoie, S. Le Faucheur, C. Fortin, P. G. C. Campbell, Aq. Toxicol. 2009, 92, 65.

[42] Y. Wu, W. X. Wang, Environ. Poll. 2011, 159 , 3097.

[43] Y. Wu, W.-X. Wang, Aq. Toxicol. 2014, 148, 122.

[44] S. Devars, C. Avilés, C. Cervantes, R. MorenoSánchez, Arch. Microbiol. 2000, 174, 175.

[45] E. Morelli, R. Ferrara, B. Bellini, F. Dini, G. Di Giuseppe, L. Fantozzi, Sci. Total Environ. 2009, $408,286$.

[46] D. J. A. Kelly, K. Budd, D. D. Lefebvre, Arch. Microbiol. 2007, 187, 45

[47] Y. Wu, W.-X. Wang, J. Haz. Mat. 2012, 217$218,271$.

[48] D. Kelly, K. Budd, D. D. Lefebvre, Appl. Environ. Microbiol. 2006, 72, 361.

[49] A. Gothberg, M. Greger. Chemosphere 2006, 65, 2096.

[50] G. Liu, Y. Cai, N. J. O’Driscoll, 'Environmental Chemistry and Toxicology of Mercury', Wiley, Hoboken, New Jersey, 2012, p. 600.
[51] D. Ben-Bassat, A. M. Mayer, Physiol. Plant. 1977, 40, 157.

[52] R. P. Mason, F. M. M. Morel, H. F. Hemond, Water Air Soil Poll. 1995, 80, 775.

[53] R. Singh, G. Dubey, V. Singh, P. Srivastava, S. Kumar, S. Prasad, Biol. Trace Element Res. 2012, 149, 262.

[54] S. D. S. Murthy, P. Mohanty, J. Biosciences 1993, $18,355$.

[55] C. M. Lu, C. W. Chau, J. H. Zhang, Chemosphere 2000, 41, 191.

[56] Y. Wu, Y. Zeng, J. Y. Qu, W.-X. Wang, Aq. Toxicol. 2012, 110-111, 133.

[57] H. Küpper, F. Küpper, M. Spiller, J. Exp. Bot. 1996, 47, 259.

[58] P. Haldimann, M. Tsimilli-Michael, Photosynthesis Res. 2002, 74, 37.

[59] P. Juneau, D. Dewez, S. Matsui, S. G. Kim, R. Popovic, Chemosphere 2001, 45, 589.

[60] P. Rai, B. Tripathi, Environ. Monit. Ass. 2009, $148,75$.

[61] M. Gupta, P. Chandra, Environ. Poll. 1998, 103, 327.

[62] C. Ding, G. Shi, X. Xu, H. Yang, Y. Xu, Plant Growth Regul. 2010, 60, 61.

[63] H. M. Wallace, A. V. Fraser, A. Hughes, Biochem. J. 2003, 376, 1.

[64] A. Elbaz, Y. Y. Wei, Q. Meng, Q. Zheng, Z. M. Yang, Ecotoxicology 2010, 19, 1285.

[65] G. Cheloni, V. I. Slaveykova, Cytometry A 2013 , $83,952$.

[66] D. W. Boening, Chemosphere 2000, 40, 1335.

[67] M. B. Ali, P. Vajpayee, R. D. Tripathi, U. N. Rai, A. Kumar, N. Singh, H. M. Behl, S. P. Singh, Bull. Environ. Contam. Toxicol. 2000, 65, 573.

[68] L. Ferrat, M. Romeo, M. Gnassia-Barelli, C. Pergent-Martini, Dis. Aquat. Org. 2002, 50, 157.

[69] Y.-A. Chen, W.-C. Chi, T.-L. Huang, C.-Y. Lin, T. T. Quynh Nguyeh, Y.-C. Hsiung, L.-C. Chia, H.-J. Huang, Plant Physiol. Biochem. 2012, 55, 23.

[70] C. Suscillon, O. D. Velev, V. I. Slaveykova, Biomicrofluidics 2013, 024109.

[71] C. Santschi, G. G. Suárez, V. I. Slaveykova, O. J. F. Martin, Nat. Sci. Rep. 2013, 3, 447. 